\title{
Cachexia and skin lesions in an acutely unwell man
}

\author{
Shilpa Manupati, Manju Krishnan, Tal Anjum
}

Department of Stroke Medicine, Abertawe Bro Morgannwg University Health Board, Port Talbot, UK

\section{Correspondence to} Dr Shilpa Manupati, mshilpa80@gmail.com

Accepted 2 June 2016

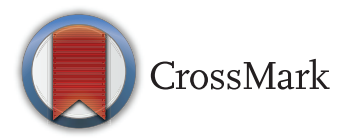

To cite: Manupati $S$ Krishnan M, Anjum T. BMJ Case Rep Published online: [please include Day Month Year] doi:10.1136/bcr-2016215153

\section{DESCRIPTION}

A 64-year-old man, a chronic alcoholic, was admitted with fall, confusion and multiple skin lesions. He was cachectic with bilateral intention tremor, dysdiadochokinesia and ataxia. Cutaneous examination showed angular stomatitis, glossitis, pressure ulcer with necrotic eschar on the right buttock (figure 1A), erythematous, weeping, pus-filled scrotal lesions (figure 2A) and oedematous, tender palms and soles (figure $3 \mathrm{~A}$ ).

Based on the clinical picture and high inflammatory markers, he was treated for sepsis (presumed cutaneous source), with appropriate intravenous antibiotics after discussion with the microbiologist. Chronic malnutrition was evident from the clinical presentation and biochemical values of low albumin, vitamin D, creatinine levels and macrocytosis, although mistimed blood samples revealed normal vitamin $\mathrm{B}_{12}$ and folate levels. Septic screen investigations were negative. CT of the head
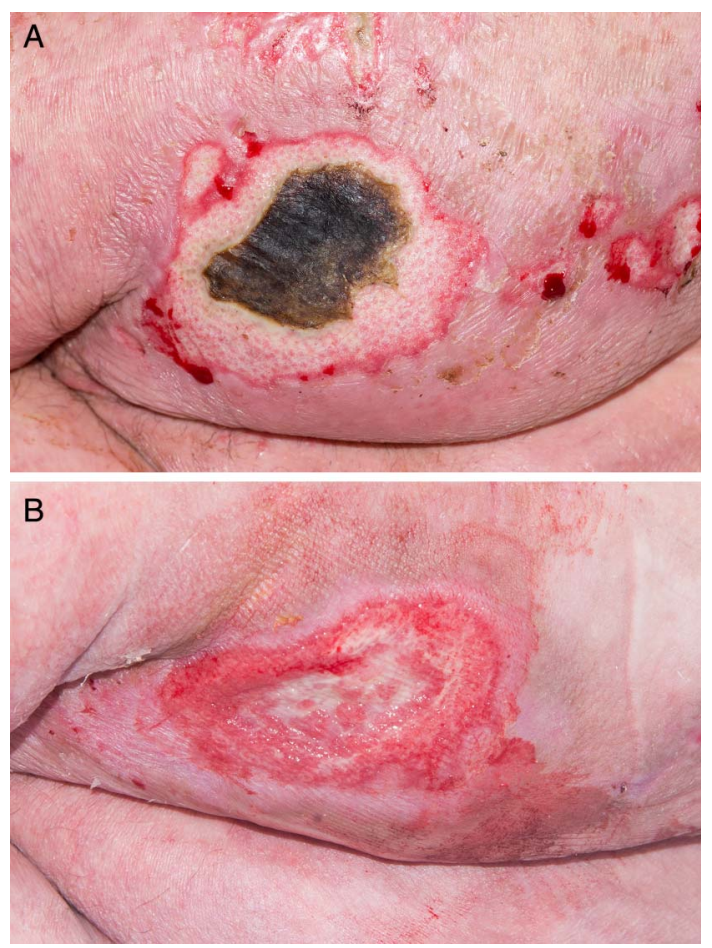

Figure 1 (A) Pressure ulcer on the buttock with necrotic eschar. (B) Healing stage. showed cerebellar atrophy. The patient was treated initially with parenteral combined vitamin B-complex and C, switched 3 days later to longterm oral supplements. Clinically, his confusion resolved and he was back to his baseline mobility. His skin lesions subsequently healed with desquamation and postinflammatory pigmentation (figures $1 \mathrm{~B}, 2 \mathrm{~B}$ and $3 \mathrm{~B}$ ).

Skin and hair signs of malnutrition should not be missed in the presence of anaemia, dermatitis and cachexia. ${ }^{1}$ The absence of classic signs and protean manifestations can lead to difficulty in diagnosis. Parenteral B vitamins should be a routine part of therapy in treating fulminant infections in the malnourished. ${ }^{2}$

This case highlights the importance of looking for hidden signs of nutritional deficiencies, especially in the high-risk population, as a lack of timely diagnosis and treatment can have devastating consequences. ${ }^{1}$
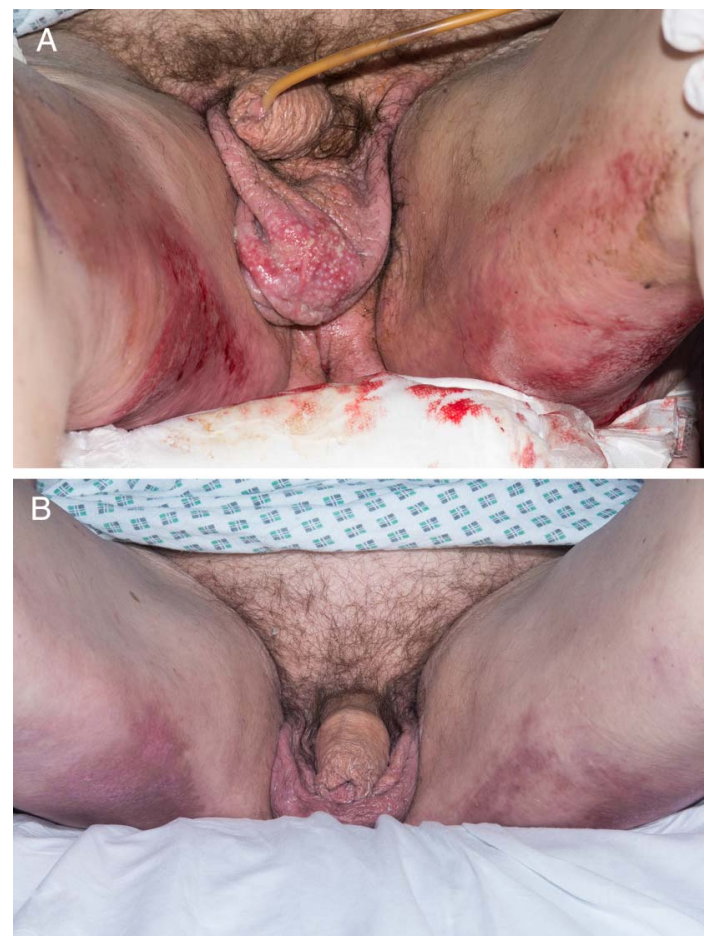

Figure 2 (A) Erythematous, weeping and pus-filled scrotal skin lesions. (B) Healing with postinflammatory pigmentation. 

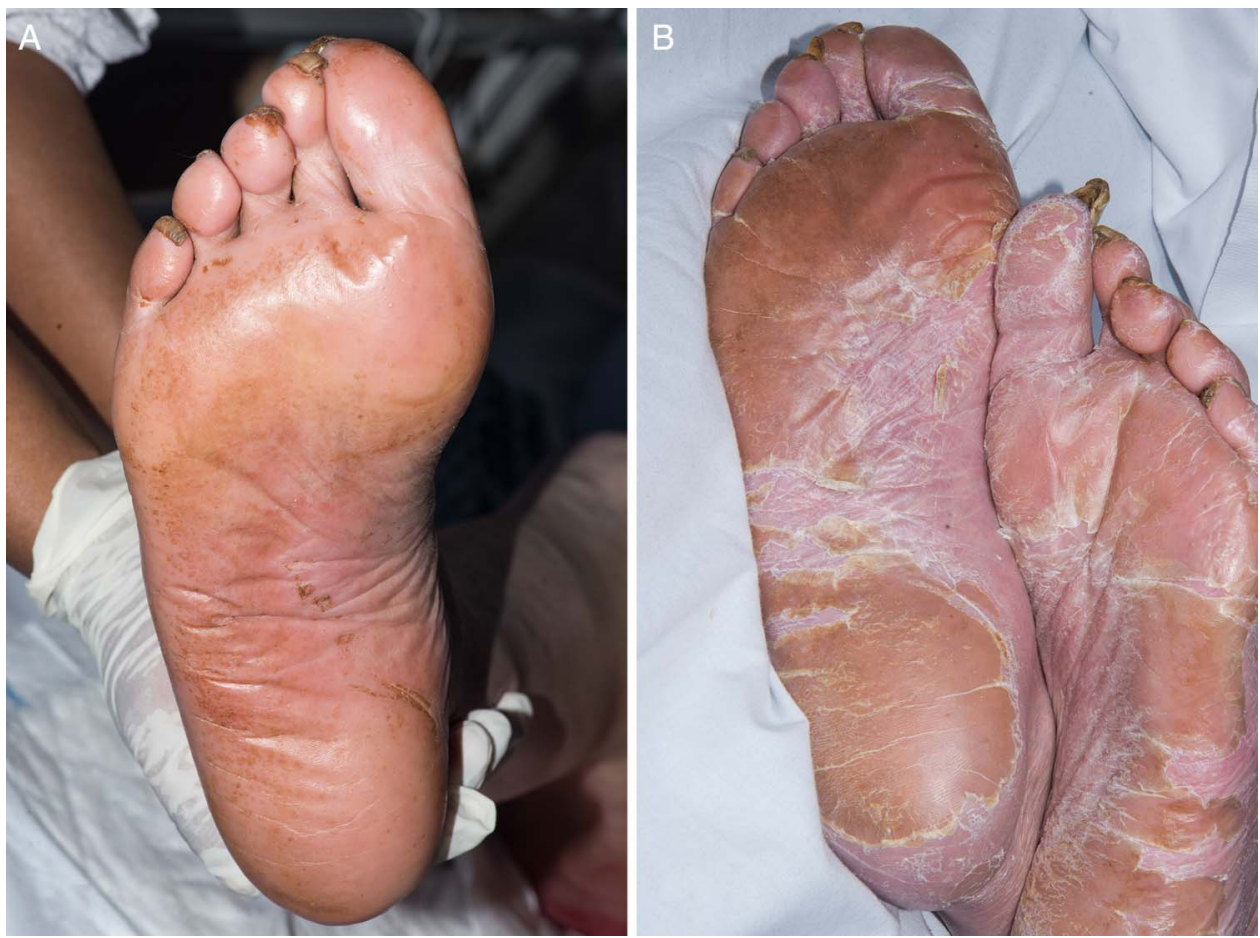

Figure 3 (A) Oedematous and tender sole. (B) Healing with desquamation.

\section{Learning points}

- Create awareness of the subtle and heterogeneous cutaneous manifestations of malnutrition, which can be overlooked in the presence of secondary infection and sepsis.

- Lack of timely appropriate high-dose vitamin supplementation can be fatal.
Contributors SM was involved in the literature search, patient consent and manuscript preparation. MK and TA were involved in the image selection and manuscript review.

Competing interests None declared.

Patient consent Obtained.

Provenance and peer review Not commissioned; externally peer reviewed.

\section{REFERENCES}

1 Kuhl J, Davis MD, Kalaaji AN, et al. Skin signs as the presenting manifestation of severe nutritional deficiency: report of 2 cases. Arch Dermatol 2004;140:521-4.

2 Lee BY, Thurmon TF. Nutritional disorders among workers in North China during national turmoil. Ann Nutr Metab 2001;45:175-80.

Copyright 2016 BMJ Publishing Group. All rights reserved. For permission to reuse any of this content visit

http://group.bmj.com/group/rights-licensing/permissions.

BMJ Case Report Fellows may re-use this article for personal use and teaching without any further permission.

Become a Fellow of BMJ Case Reports today and you can:

- Submit as many cases as you like

- Enjoy fast sympathetic peer review and rapid publication of accepted articles

- Access all the published articles

- Re-use any of the published material for personal use and teaching without further permission

For information on Institutional Fellowships contact consortiasales@bmjgroup.com

Visit casereports.bmj.com for more articles like this and to become a Fellow 